\title{
TECHNOLOGY TO INCREASE THE MANAGEMENT COMPETENCE OF FUTURE PRIMARY SCHOOL TEACHERS
}

\author{
Feruza Damirovna Qodirova
}

Phd Student, Tashkent State Pedagogical University Named After Nizami Tashkent, Uzbekistan

\section{ABSTRACT}

The concept of management competence is a topical issue from a scientific point of view. This article discusses management competence, its components, the functions of management competence and how to form this competence in primary school teachers.

KEYWORDS: - Competence, management competence, acmeological, integral, cognitive, task.

\section{INTRODUCTION}

In independent Uzbekistan, on the basis of the "National training program" and the Law "On Education" comprehensive training of primary school teachers and their continuous improvement in accordance with modern requirements is an integral part of the reform of the education system and is a priority of the state as an integral part. Indeed, the sharp increase in the volume of information due to the rapid development of science and technology has led to a high level of pedagogical and professional skills for the primary education system, which is the main foundation of continuous education, requires the training of creative teachers.

The ongoing educational reforms in our country, in contrast to traditional forms of education, have developed effective forms and methods of organizing the educational process in the primary education system, which serves to ensure the formation and development of young people as harmoniously developed individuals. output allows the creation of scientific views, pedagogical theories and didactic materials that lead to the optimization of the pedagogical and psychological foundations of education for children of primary school age.

The Concept of Higher Education of the Republic of Uzbekistan defines the responsibilities of a specialist as follows: they must be able to clearly imagine their social and cultural aspects. These ideas apply to teachers as well. Because the radical changes taking place in our society, our entry into the market relations require the teacher to be aware not only of professional knowledge, but also of economic, legal and technical knowledge. It is also important to focus 
CURRENT RESEARCH JOURNAL OF PEDAGOGICS 2(8): 27-33, August

2021 DOI: https://doi.org/10.37547/pedagogics-crjp-02-08-08

ISSN 2767-3278

(C)2021 Master Journals

Crossref do: 81 Google

Accepted 24th August, 2021 \& Published 29th August, 2021

on the primary school teacher.

One of the ways in which a teacher's pedagogical skills have a significant impact on the development of his qualifications, pedagogical abilities, pedagogical competence is to improve the skills of continuing professional education.

Today in the scientific and pedagogical community there is a heated debate about the nature and structure of professional and pedagogical competence.

Textbooks, manuals, methodical recommendations, methods and mechanisms of organization of the educational process, created on the basis of the ideas recognized in the concept of primary education, the effectiveness of education in primary school, depends on innovative ideas and tools of teaching, of course. However, it should be noted that in this pedagogical process, the role of an elementary school teacher with high pedagogical skills and professional knowledge, who can create problem situations during the lesson and suggest solutions, is of particular importance. If the primary school teacher focuses more on the fundamental foundations and general laws of the natural and social sciences, their place and importance in human society, the differential aspects of education, the primary school teacher - a set of psychological knowledge, armed with methods, factors and tools to increase the effectiveness of education, with a thorough knowledge of the scientific and theoretical foundations of mathematics, mother tongue, nature, human and social education, based on the age (physiological and psychological) characteristics of the child focuses on teaching general aspects, i.e., integrative learning. In addition, the primary school teacher should be able to direct the child to direct the elements of play activities to educational activities, to feel responsible, to make the right decisions in some problematic situations, to plan time, to teach students is also an educator responsible for the formation of the qualities of attention to the wishes, as well as the vision of a promising future, appreciating goodness. Another important quality of an elementary school teacher is that he organizes educational activities on the basis of the principles of interdependence of primary and secondary education subjects and the interdependence of primary school subjects.

There are many problems in the work of primary school teachers in urban and district schools today, including shortcomings in the use of nontraditional teaching methods in the teaching of specific subjects of primary education; inaccuracies in the assessment of students' knowledge; inability to feel the psychological state of students and, as a result, not be able to motivate them to the learning process; inability to ensure interdisciplinary communication in the learning process; cases of non-compliance with didactic principles are not fully understood. It is impossible to talk about the quality and effectiveness of education in the primary grades without finding a positive solution to these problems.

\section{Material AND METHODS}

European researchers, V.A.Adolf, N.V.Kuzmina, A.K.Markova, E.L.Pupysheva, G.S.Savolainen, L.V.Shkerin et al distinguish between different types of professional competence: methodological, innovative, managerial, psychological, creative, communicative, and others. Among the above, the teacher's management competence has a special place, because it includes a number of other competencies, in addition, it is his level that determines the level of professionalism of the specialist in the field of education.

It is known that the basis of knowledge given to students is given in primary education. It is at this stage that the knowledge that underpins the 
CURRENT RESEARCH JOURNAL OF PEDAGOGICS 2(8): 27-33, August

2021 DOI: https://doi.org/10.37547/pedagogics-crjp-02-08-08

ISSN 2767-3278

(C)2021 Master Journals

Crossref do: 81 Google

Accepted 24th August, 2021 \& Published 29th August, 2021

development of a person's consciousness and worldview is imparted. Accordingly, the spiritual, moral and professional maturity of primary school teachers is important for the development of the students they teach.

Several researchers have differed in their research on teacher management competence. In particular, according to O.V.Tumasheva, a teacher's management competence includes the acquisition of methodological knowledge, skills and methods of work, recognition of their value for both their professional activities and interactions in society, experience in solving methodological problems, sees as an integral characteristic of the individual, which implies a willingness and ability to self-education and selfimprovement [1].

T.Gushchina describes management competence as an integrated multidisciplinary professional feature of the teacher's personality and activity, generalizing the production experience, systematic acquisition of knowledge, skills and competencies in the field of methodology and an optimal combination of professional and pedagogical activities [4].

I.Kovaleva considers management competence as an integral feature of a teacher's business, personal and ethical qualities, which are methodological, methodological and research knowledge, skills, experience, motivation, ability and creative self in scientific, methodological and pedagogical activities, reflects a systemic level of readiness to implement [4]. The most important aspect of developing the personal components of a teacher's management competence is to develop his or her methodological thinking and methodological culture.

Based on the analysis of the teacher's professional activity, based on the structure of professional-pedagogical competence proposed by L.V.Shkerina, the teacher's methodological competence is divided into three components: cognitive, activity and social-personal component [2].

The activity component also includes the ability to implement the main types of methodological activities, analyze and evaluate the results of their activities, change them on the basis of their compliance with the expected, planned results.

The basis of a teacher's social and personal competence is the personal qualities required in his / her methodological activity and necessary for sufficient and active interaction with the society. As a result of studying the research of researchers can be given a number of tasks of the concept of methodological competence: acmeological, innovative, predictive, integral, stimulating, managerial, reflexive [1].

The acmeological task is aimed at achieving the professional and personal maturity of the teacher. The methodological competence of the teacher can be considered as a result of selfdevelopment of the subject of the educational process, enriching the teacher's personality with new professional qualities that raise him to a higher level of professionalism. The main "efforts" of the acmeological function of the teacher's methodological competence are aimed at developing the professional potential of the specialist in the field of education, his creativity, individuality.

The innovative task is to eliminate the existing negative stereotypes in the teacher's professional activity, the process of formation of high-level methodological skills of the teacher, the formation of analytical skills that allow schoolchildren to penetrate deeper into the essence of the teaching process depending on. In the context of the development of modern education, it is important for the teacher to understand the importance and necessity of innovative processes that take place in the school, to know innovative teaching technologies and how to implement them in the learning 
CURRENT RESEARCH JOURNAL OF PEDAGOGICS 2(8): 27-33, August

2021 DOI: https://doi.org/10.37547/pedagogics-crjp-02-08-08

ISSN 2767-3278

(C)2021 Master Journals

Crossref dof 81 Google

Accepted 24th August, 2021 \& Published 29th August, 2021

process. It should be noted that as a result of research, we can see that in the school system there is an additional motivation for students to learn through the use of innovative technologies, in particular, ICT [6].

The task of forecasting is to develop the teacher's ability to anticipate future methodological problems of professional activity, to develop models for solving them, to anticipate the consequences of decisions made.

The integral function provides a link between the subject, pedagogical, psychological, methodological knowledge and methods of activity.

The motivating task is to develop the professional motivation of the teacher, the desire to fill his subject, the pedagogical, psychological, methodological knowledge necessary for effective methodological activities, to ensure a positive attitude to the professional activity of the teacher in general. .

The task of management is, on the one hand, to manage the teacher's own activities in the educational process (planning, organization, adjustment, etc.), on the other hand, the activities of students in the acquisition of subject knowledge and activities aimed at the development of each student provides management of methods.

\section{DisCUSSION AND RESULTS}

In order to implement the above, we conducted a questionnaire survey on the professional skills of primary school teachers, their activities in the organization and management of the educational process.

The following questions were included in the questionnaire:

- Why did you choose the profession of primary school teacher?
- What are the requirements for an elementary school teacher?

- What do you know about the individual psychological characteristics of primary school students?

- Explain that the physiological state of students depends on the acquisition of knowledge, skills and abilities.

- How do you explain the essence and importance of the principles of education?

- Explain the essence of interdisciplinary communication.

An analysis of the survey results showed that the majority of primary school teachers surveyed were not able to fully explain the essence of the basic pedagogical process and concepts.

This shows that there is no work done in schools to work with primary school teachers, to analyze their lessons, to improve their skills and abilities, to master innovative pedagogical technologies. The selection and recruitment of teachers in the primary grades has been neglected by the management. There are no pedagogical councils to discuss the pedagogical activities of primary school teachers, and the existing ones approach this activity from a formal point of view. Our analysis has shown that the primary school teachers of many secondary schools do not have a sufficient level of knowledge in certain subjects, do not know the documents related to education, and are focused on improving their professional knowledge and skills. and it must be acknowledged that planned activities have not been established. Similarly, the psychological and physiological characteristics of primary school teachers, as well as the relationship between the organization and management and evaluation of the educational process, as well as the methodological aspects of education It was also clear that the skills and competencies in the field were insufficient, and that the stable connection 
CURRENT RESEARCH JOURNAL OF PEDAGOGICS 2(8): 27-33, August

2021 DOI: https://doi.org/10.37547/pedagogics-crjp-02-08-08

ISSN 2767-3278

(C)2021 Master Journals

Crossref do: 81 Google

Accepted 24th August, 2021 \& Published 29th August, 2021

between the pedagogical reality and the pedagogical process was not taken into account. Consequently, as the great Western educator A.Disterverg put it: "A good teacher never abandons his principles of education. The teacher must work independently. A bad teacher can tell the truth. A good teacher teaches students to find the truth."

The worst flaw of the old education system is that we consider primary education as a secondary activity. Let's be clear: even shallow teachers teach in the first grade. Proof of the low regard for primary education is the fact that in the former USSR, a whole system of pedagogical colleges and educational institutions was established, which mainly trained teachers who taught students in grades 1-4. However, based on the idea that simple logic itself requires the closure of the most mature and experienced coaches in the primary grades, where the child's outlook, tastes and potential are formed [1], secondary special education in the higher education system special part-time departments for the training of specialists were opened, the primary education system was enriched with modern textbooks and literature, didactic materials. However, this is not the case in all schools. For example, some secondary schools have philologists or other graduates who do not know the methods of primary education.

Another reason for the low level of knowledge of primary school teachers is the lack of training in higher education. Prospective primary school teachers should not be taught special courses in these higher education institutions, such as "Modern concepts of natural sciences", "Unique landscape" or "Innovative pedagogical technologies", "Start on the basis of information technology". The organization of the learning process in the classroom "is an approach to important course topics as a secondary subject. In addition, the curriculum in the field of "Primary education and sports, educational work" does not include classes on the subject of "Psychology of youth." However, the professional activity of a primary school teacher is mainly related to the comprehensive formation of primary school students. differ sharply in species. Young students approach elementary school teachers with all their questions about the natural and social sciences to understand the natural phenomena they see around them, the words they hear from adults, with their interest in everything. High school students, unlike them, do not ask a physics teacher questions about math or biology. This requires that primary school teachers be well versed in all areas of science.

Is that really so?

These problems require an innovative approach to the organization of the educational process in higher education, as well as the provision of systematic knowledge of interdisciplinary knowledge in the training of future primary school teachers. In order to organize pedagogical activity, a teacher must know such disciplines as pedagogical theory, philosophy, sociology, cultural studies, religion, children's anatomy and physiology, psychology, political science. It also requires knowledge of the laws of physics in order to correctly interpret objects and phenomena related to the natural sciences in the primary grades. In addition, the development of a technological approach to the educational process today makes it expedient to ensure the relevance of cybernetic sciences in the teaching of pedagogy.

Another important point is that the essence of the teaching profession and its role in the development of society, as well as the main features of the teaching profession are formed through the science of pedagogy. Research has shown that primary school teachers have low levels of skills in designing the educational process, mastering pedagogical technology, 
CURRENT RESEARCH JOURNAL OF PEDAGOGICS 2(8): 27-33, August

2021 DOI: https://doi.org/10.37547/pedagogics-crjp-02-08-08

ISSN 2767-3278

(C)2021 Master Journals

Crossref do) 81 Google

Accepted 24th August, 2021 \& Published 29th August, 2021

communicative qualities and research activities, and the reasons for this should be:

- Lack of attention of prospective teachers to individual communication with the student body during the pedagogical practice;

- lack of ability to design the educational process;

- Insufficient attention is paid to the interaction of prospective teachers;

- Insufficient knowledge of the theory and practice of pedagogy

Based on experience and analysis, we consider it appropriate to implement the following recommendations aimed at training and optimizing the requirements for primary school teachers:

- Determining the composition of higher education institutions that train primary school teachers based on their scientific and pedagogical potential, and reviewing the admission quotas allocated to them in the light of real demand and need.

- Determining the amount of subjects to be taught in the training of future primary school teachers, taking into account the psychological and physiological conditions of young students, based on today's requirements.

- To consider issues of professional development and retraining of primary school teachers directly in schools by the staff of regional teacher training and retraining institutes.

- In order to prepare teachers with universal knowledge, taking into account the age-specific curiosity of primary school students, the curriculum includes "Modern concept of natural sciences", "Unique view of the structure of the universe", "Psychology of youth", Introduction of special courses such as "Pedagogical psychology".

- Development of lesson plans for the teaching of pedagogy in higher education institutions based on the principles of interdisciplinary communication, based on the developed theoretical ideas of teaching.

- The cognitive component of a teacher's management competence includes an understanding that the teacher has a system of methodological knowledge and that this knowledge is important and relevant for both himself or herself and for professional growth.

The development of management competence goes hand in hand with the changes that take place directly in its activities, the motives, the goals, the application of new tools and methods, the methods and programs of action. As a result of various pedagogical changes, the methodological abilities of the teacher are formed. A teacher with pedagogical skills is a teacher who is able to overcome the difficulties of upbringing, who can understand the peculiarities of the younger generation, who can feel their feelings, whose inner world is delicate and weak, is a person with a deep scientific mind, who is able to see the various difficulties in the life of the child and approach them skillfully, combining knowledge and creativity.

\section{Conclusion}

Thus, based on the study and analysis of scientific sources, the following conclusions can be drawn:

Management competence, which provides teachers with the ability to recognize and solve methodological problems that arise in the course of pedagogical activity, is a key component of professional competence.

The teacher's management competence has its own components and on the basis of them serves as a basis for the development of the existing management competence of the teacher throughout his activity. 
CURRENT RESEARCH JOURNAL OF PEDAGOGICS 2(8): 27-33, August

2021 DOI: https://doi.org/10.37547/pedagogics-crjp-02-08-08

ISSN 2767-3278

(C)2021 Master Journals

Crossref dof 81 Google

Accepted 24thAugust, 2021 \& Published 29thAugust, 2021

Future primary school teachers will be able to develop their methodological knowledge by studying the mentioned tasks of management competence and applying them in practice.

\section{REFERENCES}

1. O.V. Tumasheva on the methodological competence of the teacher / Bulletin of the KSPU named after V.P.Astafieva. Method of teaching. 2009 (1).

2. Shkerina, L.V. Monitoring the quality of professional and pedagogical training of a future teacher in a pedagogical university: teaching method. allowance / L.V.Shkerin, V.A.Adolf, G.S.Savolainen, M.B.Shashkina, M.V.Litvintsev; Krasnoyar. state un-t them. V.P.Astafieva. - Krasnoyarsk, 2004 -- 244 p.

3. O.P.Filatova The process of forming the methodological competence of teachers in the development of audiovisual teaching technologies. Scientific and theoretical journal Issue. 1 (14) 2013

4. E.V.Maltseva. Development of the professional competence of primary school students in the system of continuous pedagogical education / Abstract of the dissertation for the degree of candidate of pedagogical sciences, $2006-6 \mathrm{p}$

5. Markova A.K, Psychology of teacher's work / A.K.Markov. - M .: Education, 1993.-192 p

6. P.I. Ivanov, M.E. Zufarova, General Psychology $\mathrm{T}$.: Publishing House of the National Society of Philosophers of Uzbekistan, 2008- 137 pages 